\title{
PENGEMBANGAN MEDIA PEMBELAJARAN MULTIMEDIA INTERAKTIF MATA PELAJARAN SEJARAH BERBASIS CONTEXTUAL TEACHING LEARNING (CTL)
}

\author{
Lia Andryani, Abdul Hamid $K^{2}$., R. Mursid ${ }^{3}$ \\ ${ }^{1}$ SMA PAB 8 Saentis, Deli Serdang, Sumatera Utara \\ ${ }^{2,3}$ FT Universitas Negeri Medan, Sumatera Utara \\ lia.andryani@gmail.com
}

\begin{abstract}
Abstrak: Tujuan penelitian ini untuk: (1) mengembangkan media pembelajaran multimedia interaktif berbasis CTL pada mata pelajaran Sejarah layak digunakan; dan (2) mengetahui keefektifan media pembelajaran multimedia interaktif berbasis CTL yang dapat meningkatkan hasil belajar sejarah. Penelitian ini dilakukan di SMA PAB 8 Saentis. Metode penelitian adalah model pengembangan Bord dan Gall dengan desain pembelajaran Model Dick dan Carey. Subjek penelitian terdiri dari 40 siswa kelas X. Untuk pengembangan produk menggunakan 2 orang ahli desain pembelajaran, 2 orang ahli materi, 2 orang ahli perangkat lunak, 3 orang siswa uji coba satu-satu, dan 9 orang siswa kelas kelompok kecil. Hasil penelitian diperoleh terdapat perbedaan yang signifikan dan berarti antara hasil belajar sejarah siswa yang diajarkan dengan menggunakan multimedia pembelajaran interaktif dengan rata-rata hasil belajar sejarah siswa yang diajarkan dengan menggunakan media pembelajaran. Keefektifan multimedia pembelajaran interaktif lebih tinggi dari pembelajaran dengan media pembelajaran powerpoint.
\end{abstract}

Kata Kunci: multimedia interaktif, Sejarah, Berbasis Contextual Teaching Learning

Abstract: The purpose of this study is to: (1) develop CTL-based interactive multimedia learning media on History subjects worthy of use; and (2) knowing the effectiveness of CTLbased interactive multimedia learning media that can improve the results of historical learning. This research was conducted in SMA PAB 8 Saentis. The research method is the development model of Bord and Gall with the learning design of the Dick and Carey Models. The research subjects consisted of 40 class $X$ students. For product development using 2 learning design experts, 2 material experts, 2 software experts, 3 one-on-one students, and 9 small group students. The results showed that there were significant and meaningful differences between the historical learning outcomes of students who were taught using interactive learning multimedia with the average results of students' historical learning taught using learning media. The effectiveness of multimedia interactive learning is higher than learning with powerpoint learning media.

Keywords: interactive multimedia, history, based on contextual teaching

\section{PENDAHULUAN}

Masalah pendidikan yang menjadi perhatian saat ini adalah sebagian besar siswa tidak mampu menghubungkan antara apa yang mereka pelajari dengan bagaimana pemanfaatannya dalam kehidupan nyata. Hal ini disebabkan model pembelajaran yang mereka terima lebih menonjolkan tingkat hafalan materi tanpa diikuti pemahaman atau pengertian mendalam, yang dapat diterapkan ketika mereka berhadapan dengan situasi baru dalam kehidupannya (Muslich, 2007:40).

Dalam bidang pendidikan, proses pembelajaran diidentikkan dengan proses penyampaian informasi atau komunikasi. Dalam hal ini media pembelajaran merupakan bagian yang tak terpisahkan pada lembaga pendidikan. Pemanfaatan media pembelajaran merupakan upaya kreatif dan sistematis untuk menciptakan pengalaman yang dapat 
membelajarkan siswa sehingga pada akhirnya lembaga pendidikan akan mampu menghasilkan lulusan yang berkualitas. Sesuai dengan pendapat Hamalik (2003:63) bahwa media pembelajaran merupakan unsur penunjang dalam proses belajar mengajar agar terlaksana dengan lancar dan efektif.

Salah satu upaya peningkatan kualitas dan kuantitas program pendidikan adalah dengan peningkatan kualitas pembelajaran. Pembelajaran merupakan proses terjadinya interaksi antara siswa dengan sumber belajar, namun proses pembelajaran yang berlangsung kenyataannya sebagian besar masih berpusat pada pengajar, dimana proses pembelajaran yang berkualitas idealnya adalah pembelajaran yang dapat membantu dan memfasilitasi pembelajar untuk mengembangkan potensi dirinya secara optimal, serta mampu mencapai tujuan yang ditetapkan secara efektif, dengan berorientasi pada minat, kebutuhan, dan kemampuan pebelajar.

Salah satu upaya perbaikan yang dilakukan pemerintah dalam meningkatkan mutu pembelajaran di sekolah adalah dengan merevisi kurikulum pembelajaran ke arah yang lebih bermutu, yaitu dengan mengeluarkan Kurikulum 2013. Kehadiran kurikulum 2013 tidak lepas dari kurikulum sebelumnya, yakni KTSP tahun 2006. Kurikulum 2013 sebagai hasil dari penjabaran Permendikbud No. 65 Tahun 2013 tentang Standar Proses Pendidikan Dasar dan Menengah yang mengisyaratkan tentang perlunya proses pembelajaran yang dipandu dengan kaidah-kaidah pendekatan saintifik atau ilmiah. Sebagaimana disebutkan Sudrajat (2013) bahwa kehadiran kurikulum 2013 menjadikan siswa lebih aktif dalam mengkonstruksi pengetahuan dan keterampilannya, juga dapat mendorong siswa untuk melakukan penyelidikan guna menemukan fakta-fakta dari suatu fenomena atau kejadian. Artinya, dalam proses pembelajaran, siswa dibelajarkan dan dibiasakan untuk menemukan kebenaran ilmiah, bukan diajak untuk beropini dalam melihat suatu fenomena. Dengan demikian, kurikulum 2013 lebih menargetkan pada capaian keberhasilan siswa dalam setiap proses belajarnya.
Dalam kurikukum 2013, Sejarah yang terdiri dari materi geografi, sejarah, ekonomi dan sosiologi yang disampaikan secara sistematis, terpadu dan komprehensif. Dengan banyaknya materi yang harus dikuasai oleh siswa dalam materi Sejarah dibandingkan dengan materi mata pelajaran lain yang hanya satu materi (misal PPKn), hal ini mengakibatkan $47 \%$ siswa yang mendapatkan hasil belajar yang tidak maksimal dan kurang dari KKM. Apalagi kalau guru dalam menyampaikan materi tidak pandai memanfaatkan media atau alat peraga dan menggunakan metode yang masih konvensional, bisa dipastikan kegiatan belajar mengajar di kelas akan membosankan dan konsep dasar yang akan disampaikan ke anak didik akan mengambang/ tidak mengena. Salah satu mata pelajaran dalam Sejarah adalah pembelajaran IPS-sejarah.

Pembelajaran sejarah di sekolah saat ini masih merupakan salah satu topik yang menjadi fokus perhatian para ahli pendidikan sejarah. Hal ini dikarenakan masih banyak persoalan dalam pembelajaran sejarah di sekolah. Banyaknya permasalahan itu antara lain adalah metode pembelajaran yang digunakan dipandang belum sesuai untuk diterapkan pada proses pembelajaran. Selain itu media yang digunakan dalam pembelajaran kurang mendukung proses pembelajaran atau kurang sesuai dengan metode pembelajaran yang digunakan.

Hal tersebut yang tercermin di SMA PAB 8 Saentis, kegiatan pembelajaran Sejarah ditetapkan 2 jam pelajaran setiap minggunya. Dengan alokasi waktu yang hanya 2 jam dan jumlah materi yang harus dikuasai demikian luasnya, ditunjang dengan input siswa yang rendah menyebabkan nilai yang dicapai sebagai hasil belajar masih rendah/ di bawah KKM. Hal ini disebabkan siswa kesulitan untuk memahami banyaknya materi pelajaran IPS-Sejarah yang harus dipahami, di samping itu guru dalam menyampaikan materi masih menggunakan metode yang konvensional yaitu ceramah. Hal ini dapat dilihat dari hasil ulangan harian pertama pada Standar Kompetensi "Menganalisis peradaban Indonesia dan dunia", nilai yang dicapai oleh siswa kelas X pada tahun pelajaran 2013/2014 yang mencapai kriteria ketuntasan minimal (KKM) hanya 15 siswa dari 32 siswa di kelas 
$\mathrm{X}$ atau $46,88 \%$, batas ketuntasan untuk mata pelajaran IPS-Sejarah yang ditetapkan dalam kurikulum sekolah adalah 60\%, sehingga terdapat kesenjangan $13,12 \%$. Pada ulangan remidi dari 15 anak yang belum tuntas, yang kemudian mencapai KKM hanya 8 anak, secara keseluruhan jumlah anak yang mencapai KKM 17 siswa dari 32 siswa atau $53,13 \%$ sehingga belum memenuhi ketuntasan secara klasikal. Fakta rendahnya hasil belajar IPS-Sejarah Terpadu ini harus menjadi perhatian guru mata pelajaran.

Pada kenyataannya terkadang guru dalam memilih bahan ajar, media pembelajaran dan metode pembelajaran belumlah tepat, sehingga pembelajaran tidak dapat mencapai kompetensi yang diharapkan. Guru baru sebatas memanfaatkan metode ceramah bervariasi serta penugasan kepada siswa. Secara operasional, guru menjelaskan materi kepada siswa kemudian memberikan contoh-contoh dalam kehidupan nyata. Setelah selesai menerangkan materi, guru menyuruh siswa untuk mengerjakan soal yang terdapat dalam buku paket maupun LKS secara mandiri. Siswa kemudian disuruh maju ke depan kelas satu per satu untuk memberikan jawaban setiap soal yang dikerjakan.

Berdasarkan uraian di atas nampak adanya kesenjangan antara kondisi nyata dan harapan. Kesenjangan pokok dari subyek yakni pada kondisi awal hasil belajar Sejarah yang rendah sedangkan kondisi akhir yang diharapkan hasil belajar Sejarah meningkat. Berdasarkan data di atas dapat dilihat bahwa cukup banyak siswa yang nilainya berada di bawah KKM, yaitu sebanyak 50 - 78 siswa setiap tahun pelajarannya. Adanya nilai siswa yang masih kurang memuaskan dalam mata pelajaran Sejarah ini merupakan masalah yang serius karena mata pelajaran ini merupakan salah satu mata pelajaran yang diujikan. Dengan rendahnya prestasi belajar siswa pada mata pelajaran Sejarah di SMA PAB 8 Saentis, maka siswa dituntut untuk aktif dalam belajar.

Dari informasi yang diberikan pengawas sekolah Dinas Pendidikan diperoleh kenyataan bahwa permasalahan dalam pembelajaran sejarah selama ini, guru masih menggunakan penyampaian secara lisan (ceramah) ataupun diskusi tanpa menguraikan lebih mendalam materi yang dipelajari. Guru mengajar cenderung text-book oriented serta menggunakan media konvensional saja. Siswa kesulitan untuk memahami konsep akademik seperti yang diajarkan selama ini, yaitu menggunakan sesuatu yang abstrak dengan metode ceramah. Pembelajaran yang berorientasi pada target penguasaan materi terbukti hanya mampu mengantarkan siswa mengingat-ingat materi pelajaran dalam waktu yang relatif pendek, tetapi seringkali anak tidak memahami dan mengetahui secara mendalam. Pengetahuan yang didapat hanya bersifat hafalan menyebabkan anak akan mudah lupa, sehingga gagal dalam membekali anak untuk memecahkan masalah dalam waktu yang lama Sebagai akibatnya muncul kebosanan dan kejenuhan dari siswa untuk belajar lebih baik. Kondisi ini akan membuat siswa semakin kurang memahami dan mengerti akan hakikat sejarah itu sendiri.

Dalam pembelajaran di kelas, ketika guru kurang tepat menggunakan metode dan media dapat menyebabkan pembelajaran di kelas yang menoton dan membosankan. Selain itu, siswa dominan hanya mengikuti/ melihat dan mendengarkan penjelasan guru, sehingga siswa cenderung malas terlibat aktif dalam pembelajaran di kelas. Salah satu usaha untuk mengatasi keadaan demikian ialah penggunaan media secara terintegrasi dalam proses belajar mengajar, karena fungsi media dalam keadaan tersebut di samping sebagai penyaji stimulus informasi, sikap dan lain-lain dan juga untuk meningkatkan keserasian dalam penerimaan informasi.

Dalam hal-hal tertentu media juga berfungsi untuk mengatur langkah-langkah kemajuan serta untuk memberikan umpan balik. Di samping itu, peran media sebagai alat bantu mengajar juga dapat meningkatkan prestasi belajar siswa jika dirancang sedemikian rupa sehingga siswa benar-benar dapat memanfaatkannya sebaik mungkin. Dengan adanya media pembelajaran diharapkan dapat mempertinggi hasil belajar yang dicapainya. Selanjutnya untuk melatih keterampilan siswa untuk mengaitkan dan menerapkan konsep pada kehidupan seharihari maka dibutuhkan suatu kreativitas pendidik dalam mengembangkan multimedia interaktif dengan menggunakan suatu pendekatan pembelajaran yang dapat 
memfasilitasi siswa untuk mengembangkan keterampilan. Pendekatan pembelajaran yang dipandang tepat adalah pendekatan kontekstual.

Pendekatan kontekstual merupakan konsep pembelajaran yang membantu guru untuk mengaitkan antara materi ajar dengan situasi dunia nyata siswa, yang dapat mendorong siswa membuat hubungan antara pengetahuan yang dipelajari dengan penerapannya dalam kehidupan para siswa sebagai anggota keluarga dan masyarakat (Sardirman, 2007). Dengan menggunakan multimedia interaktif berbasis kontekstual maka siswa dapat diarahkan untuk dapat menjelaskan fenomena nyata dan menyelesaikan permasalahan dalam kehidupan sehari-hari dengan dibekali penguasaan konsep yang mereka bangun sendiri lewat pengamatan visual multimedia. Pada akhirnya multimedia interaktif berbasis kontekstual selain diharapkan menjadi lebih efektif, interaktif, menarik, tidak membosankan, dan lebih bermakna. Berdasarkan hal tersebut maka perlu dilakukan pengembangan multimedia pembelajaran interaktif pada mata pelajaran sejarah standar kompetensi menganalisis peradaban Indonesia dan dunia pada siswa SMA PAB 8 Saenties.

\section{METODE}

Penelitian ini dilaksanakan di SMA PAB 8 Saentis Kabupaten Deli Serdang pada siswa kelas X semester ganjil Tahun Pelajaran 2015/2016. Model pengembangan yang digunakan dalam media pembelajaran interaktif ini adalah model pengembangan Bord dan Gall dengan desain pembelajaran Model Dick dan Carey. Adapun langkahlangkah tahapan pengembangannya adalah sebagai berikut:
1. Melakukan
penelitian
pendahuluan

a. Identifikasi kebutuhan pembelajaran dan menentukan standar kompetensi mata pelajaran

b. Melakukan analisis pembelajaran

c. Mengidentifikasi karakteristik dan perilaku awal siswa

d. Menulis kompetensi dasar dan indikator

e. Menulis tes acuan patokan

f. Menyusun strategi pembelajaran yang terdiri dari: (1) penjelasan tentang tujuan instruksional; (2) penjelasan relevansi isi pelajaran baru; (3) penjelasan tentang materi pelajaran atau konsep, prinsip, dan prosedur yang akan dipelajari siswa; (4) tes formatif; dan (5) tindak lanjut.

g. Mengembangkan bahan pembelajaran

2. Pembuatan desain software, yang meliputi:

a. Pembuatan naskah

b. Pembuatan storyboard

c. Pembuatan flowchart view

3. Pengumpulan bahan, yang meliputi:

a. Pembuatan dan pengumpulan gambar (image) dan animasi

b. Perekaman dan pengumpulan audio

4. Mengembangkan dan membuat media pembelajaran interaktif

5. Review dan uji coba produk

6. Uji keefektifan produk

Prosedur pengembangan yang akan ditempuh untuk menghasilkan produk media pembelajaran interaktif dibagi 6 tahap, yaitu: (1) melakukan penelitian pendahuluan; (2) pembuatan desain software; (3) pengumpulan bahan; (4) membuat dan memproduksi media pembelajaran interaktif; (5) review atau uji lapangan dalam rangka evaluatif dan revisi produk, evaluasi formatif terus berlangsung selama proses pengembangan mulai dari tahap analisis, desain, produksi maupun implementasi sampai diperoleh hasil yang sesuai dengan tujuan yang telah ditetapkan; dan (6) uji keefektifan produk, sebagaimana Gambar 1 berikut. 

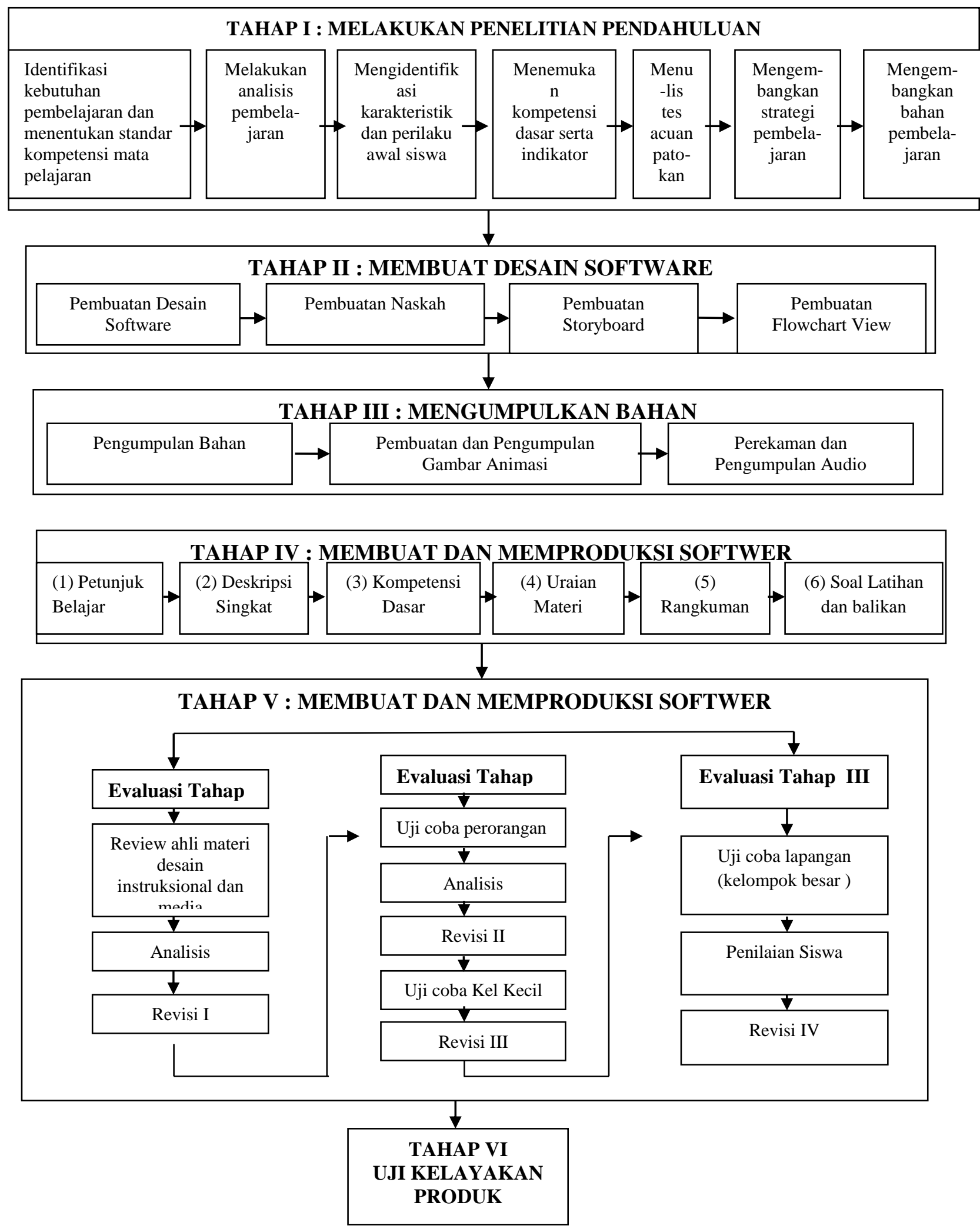

Gambar 1. Bagan Prosedur Pengembangan Media Pembelajaran Multimedia Interaktif Perpaduan Model Bord \& Gall dan Dick \& Carey 
Produk pengembangan media pembelajaran interaktif memerlukan balikanbalikan dalam rangka evaluasi formatif. Balikan-balikan tersebut diperoleh dari para subjek yang terdiri dari 2 orang ahli desain pembelajaran, 2 orang ahli materi, 2 orang ahli perangkat lunak, dan pemakai produk yaitu siswa SMA PAB 8 Saentis Kabupaten Deli Serdang yang terdiri dari 3 orang siswa kelas X untuk uji coba satu-satu, 9 orang siswa kelas X untuk uji coba kelompok kecil.

Analisis pada penelitian ini menggunakan teknik analisis kuantitatif. Sebelum dilakukan uji hipotesis, terlebih dahulu dilakukan uji persyaratan yaitu uji normalitas dan uji homogenitas. Uji normalitas dilakukan untuk mengetahui apakah skor variabel yang diteliti berasal dari populasi yang berdistribusi normal. Gejala yang diamati berdistribusi normal jika $\mathrm{L}_{\text {hitung }}<$ $\mathrm{L}_{\text {tabel }}$ pada signifikan 0,005 . Untuk menguji homogeitas data, digunakan uji kesamaan dua varians menggunakan Uji Fisher (Uji F).

Untuk melihat keefektifan media pembelajaran interaktif yang dieksperimenkan digunakan rumus perhitungan efektivitas berikut (Purwanto, 2004:112) yaitu:

$$
\mathrm{X}=\frac{\mathrm{R}}{\mathrm{N}} \times 100 \%
$$

\section{HASIL PENELITIAN}

Hasil analisis penilaian dan tanggapan oleh kelompok kecil direvisi sesuai kritik dan saran agar media dapat dilanjutkan ke uji lapangan sebagaimana tabel 2 berikut.

Tabel 2. Skor Penilaian dan Tanggapan Media Pembelajaran Interaktif Uji Lapangan di SMA PAB 8 Saentis Tentang Aspek Pembelajaran

\begin{tabular}{|c|c|c|c|c|c|c|c|}
\hline \multirow{2}{*}{ No. } & \multirow{2}{*}{ Indikator Penilaian } & \multicolumn{5}{|c|}{ Skor Diberikan Responden } & \multirow{2}{*}{ Jumlah } \\
\hline & & 1 & 2 & 3 & 4 & 5 & \\
\hline 1 & Kejelasan judul program & - & - & 1 & 2 & 6 & 9 \\
\hline 2 & Kejelasan penyajian petunjuk belajar & - & - & 1 & 2 & 6 & 9 \\
\hline 3 & Keruntunan penyajian materi & - & - & 2 & 1 & 6 & 9 \\
\hline 4 & Kemudahan dalam memahami materi & - & - & 2 & 1 & 6 & 9 \\
\hline 5 & $\begin{array}{l}\text { Materi dapat diulang setiap saat sehingga } \\
\text { meningkatkan daya ingat }\end{array}$ & - & - & 1 & 1 & 7 & 9 \\
\hline 6 & Pemberian contoh video/ gambar & - & - & 2 & 1 & 6 & 9 \\
\hline 7 & Terdapat soal-soal tes & - & - & 2 & 2 & 5 & 9 \\
\hline 8 & $\begin{array}{l}\text { Kejelasan petunjuk mengerjakan tes } \\
\text { (evaluasi) }\end{array}$ & - & - & 1 & 3 & 5 & 9 \\
\hline 9 & Kesempatan mengerjakan tes & - & - & 1 & 1 & 7 & 9 \\
\hline 10 & Feedback jawaban pada tes & - & - & 1 & 2 & 6 & 9 \\
\hline & Jumlah & - & - & 14 & 16 & 60 & \\
\hline & Persentase (\%) & - & - & 15,6 & 17,7 & 66,7 & \\
\hline
\end{tabular}

Dari Tabel 2 di atas diperoleh responden yang memberikan skor 1 (tidak baik) dan skor 2 (kurang baik) tidak ada, pada skor 3 (cukup) sebesar 15,6\%, skor 4 (baik) sebesar 17,8\%, dan skor 5 (sangat baik) sebesar 66,7\%. Dengan demikian responden kelompok kecil dominan memberikan tanggapan sangat baik terhadap kualitas media pembelajaran interaktif sejarah tentang aspek pembelajaran yaitu sebesar $66,7 \%$. 
Tabel 3. Skor Penilaian dan Tanggapan Media Pembelajaran Interaktif Uji Lapangan di SMA PAB 8 Saentis Tentang Aspek Materi

\begin{tabular}{|c|c|c|c|c|c|c|c|}
\hline \multirow{2}{*}{ No. } & \multirow{2}{*}{ Indikator Penilaian } & \multicolumn{5}{|c|}{ Skor Diberikan Responden } & \multirow{2}{*}{ Jumlah } \\
\hline & & 1 & 2 & 3 & 4 & 5 & \\
\hline 1 & Kejelasan dalam penguraian materi & - & - & 2 & 2 & 5 & 9 \\
\hline 2 & Kesesuaian materi dengan kebutuhan siswa & - & - & 1 & 2 & 6 & 9 \\
\hline 3 & Kebermanfaatan materi pembelajaran & - & - & 2 & 2 & 5 & 9 \\
\hline 4 & Faktualisasi isi materi & - & - & 2 & 2 & 5 & 9 \\
\hline 5 & Kejelasan penggunaan bahasa dalam materi & - & - & 2 & 2 & 5 & 9 \\
\hline 6 & Kesesuaian bahasa dengan sasaran pengguna & - & - & 2 & 1 & 6 & 9 \\
\hline 7 & $\begin{array}{l}\text { Kesesuaian gambar dalam memperjelas } \\
\text { materi }\end{array}$ & - & - & 2 & 2 & 5 & 9 \\
\hline 8 & Ketepatan pengguna video dalam contoh & - & - & 1 & 3 & 5 & 9 \\
\hline 9 & Ketepatan isi video dengan materi & - & - & 2 & 2 & 5 & 9 \\
\hline 10 & Kejelasan informasi dalam ilustrasi video & - & - & 1 & 1 & 7 & 9 \\
\hline & Jumlah & - & - & 17 & 19 & 54 & \\
\hline & Persentase $(\%)$ & - & - & 189 & 21.1 & 60,0 & \\
\hline
\end{tabular}

Dari Tabel 3 di atas diperoleh responden yang memberikan skor 1 (tidak baik) dan skor 2 (kurang baik) tidak ada, pada skor 3 (cukup) sebesar 18,9\%, skor 4 (baik) sebesar 21,1\%, dan skor 5 (sangat baik) sebesar 60,0\%. Dengan demikian responden kelompok kecil dominan memberikan tanggapan sangat baik terhadap kualitas media pembelajaran interaktif sejarah tentang aspek materi yaitu sebesar 60,0\%.

Tabel 4. Skor Penilaian dan Tanggapan Media Pembelajaran Interaktif Uji Lapangan di SMA PAB 8 Saentis Tentang Aspek Pemrograman

\begin{tabular}{|c|c|c|c|c|c|c|c|}
\hline \multirow{2}{*}{ No. } & \multirow{2}{*}{ Indikator Penilaian } & \multicolumn{5}{|c|}{ Skor Diberikan Responden } & \multirow{2}{*}{ Jumlah } \\
\hline & & 1 & 2 & 3 & 4 & 5 & \\
\hline 1 & Kemudahan pemakaian program & - & - & 2 & 1 & 6 & 9 \\
\hline 2 & Kemudahan memilih menu program & - & - & 1 & 2 & 6 & 9 \\
\hline 3 & Kebebasan memilih materi untuk dipelajari & - & - & 2 & 2 & 5 & 9 \\
\hline 4 & Kemudahan berinteraksi dengan program & - & - & 3 & 1 & 5 & 9 \\
\hline 5 & Kemudahan ke luar dari program & - & - & 2 & 1 & 6 & 9 \\
\hline 6 & Kecepatan fungsi tombol (kinerja navigasi) & - & - & 2 & 2 & 5 & 9 \\
\hline 7 & Kecepatan reaksi button (tombol navigasi) & - & - & 2 & 2 & 5 & 9 \\
\hline 8 & Kemudahan pengaturan pencarian halaman & - & - & 2 & 2 & 5 & 9 \\
\hline 9 & Kemudahan pengaturan menjalankan video & & & 2 & 1 & 6 & 9 \\
\hline 10 & Kompabilitas sistem operasi & - & - & 3 & 1 & 5 & 9 \\
\hline & Jumlah & - & - & 21 & 15 & 54 & \\
\hline & Persentase (\%) & - & - & 23,3 & 16,7 & 60,0 & \\
\hline
\end{tabular}

Dari Tabel 4 di atas diperoleh responden yang memberikan skor 1 (tidak baik) dan skor 2 (kurang baik) tidak ada, pada skor 3 (cukup) sebesar 23,3\%, skor 4 (baik) sebesar 16,7\%, dan skor 5 (sangat baik) sebesar 60,0\%. Dengan demikian responden kelompok kecil dominan memberikan tanggapan sangat baik terhadap kualitas media pembelajaran interaktif sejarah tentang aspek pemrograman yaitu sebesar $60,0 \%$. 
Tabel 5. Skor Penilaian dan Tanggapan Media Pembelajaran Interaktif Uji Lapangan di SMA PAB 8 Saentis Tentang Aspek Tampilan Multimedia

\begin{tabular}{|c|c|c|c|c|c|c|c|}
\hline \multirow{2}{*}{ No. } & \multirow{2}{*}{ Indikator Penilaian } & \multicolumn{5}{|c|}{ Skor Diberikan Responden } & \multirow{2}{*}{ Jumlah } \\
\hline & & 1 & 2 & 3 & 4 & 5 & \\
\hline 1 & Pemilihan jenis dan ukuran huruf & - & - & 3 & 1 & 5 & 9 \\
\hline 2 & Keterbatasan teks dan tulisan & - & - & 1 & 2 & 6 & 9 \\
\hline 3 & Kejelasan pemilihan warna teks & - & - & 2 & 2 & 5 & 9 \\
\hline 4 & Kualitas tampilan & - & - & 1 & 3 & 5 & 9 \\
\hline 5 & Sajian animasi & - & - & 1 & 2 & 6 & 9 \\
\hline 6 & Kejelasan suara dan narasi & - & - & 2 & 2 & 5 & 9 \\
\hline 7 & $\begin{array}{l}\text { Kemenarikan tampilan gambar/ } \\
\text { contoh }\end{array}$ & - & - & 2 & 1 & 6 & 9 \\
\hline 8 & Kejelasan kualitas video & - & - & 1 & 2 & 6 & 9 \\
\hline 9 & Pemilihan backsound & - & - & 2 & 1 & 6 & 9 \\
\hline 10 & Kesesuaian porsi warna & - & - & 3 & 1 & 5 & 9 \\
\hline & Jumlah & - & - & 18 & 17 & 55 & \\
\hline & Persentase $(\%)$ & - & - & 20,0 & 18,9 & 61,1 & \\
\hline
\end{tabular}

Dari Tabel 5 di atas diperoleh data bahwa responden yang memberikan skor 1 (tidak baik) dan skor 2 (kurang baik) tidak ada, pada skor 3 (cukup) sebesar 20,0\%, skor 4 (baik) sebesar $18,9 \%$, dan skor 5 (sangat baik) sebesar 61,1\%. Dengan demikian responden pada kelompok kecil secara dominan memberikan tanggapan yang sangat baik terhadap kualitas media pembelajaran interaktif sejarah tentang aspek tampilan multimedia yaitu sebesar $61,1 \%$.

Kesimpulan dari hasil penilaian dan tanggapan dari uji lapangan pada aspek pembelajaran, aspek materi, aspek pemrograman, dan aspek tampilan multimedia menunjukkan bahwa secara keseluruhan dapat digolongkan dalam kriteria "Sangat Baik", yaitu dengan ratarata pilihan jawaban yang sangat baik lebih besar dari $60 \%$.

Dari perhitungan uji normalitas data digunakan untuk mengetahui apakah sampel penelitian berasal dari populasi yang berdistribusi normal atau tidak. Pengujian normalitas data dilakukan dengan menggunakan Uji Lilliefors terhadap dua kelompok sampel. Rangkuman hasil perhitungan uji normalitas dapat dilihat pada Tabel 6 berikut.
Tabel 6. Rangkuman Hasil Perhitungan Normalitas Data

\begin{tabular}{clccc}
\hline No & \multicolumn{1}{c}{ Kelompok } & dk & $\mathbf{L}_{\text {hitung }}$ & $\mathbf{L}_{\text {tabel }}$ \\
\hline 1 & $\begin{array}{l}\text { Pembelajaran } \\
\text { dengan } \\
\text { multimedia } \\
\text { pembelajaran } \\
\text { interaktif }\end{array}$ & 39 & 0,10 & 0,140 \\
\hline 2 & $\begin{array}{l}\text { Pembelajaran } \\
\text { dengan media } \\
\text { pembelajaran } \\
\text { powerpoint }\end{array}$ & 39 & 0,09 & 0,140 \\
& Pada Tabel 6 di atas diperoleh bahwa
\end{tabular}

data hasil belajar sejarah siswa yang menggunakan multimedia interaktif berdistribusi normal. Hal ini diketahui dari besar $\mathrm{L}_{\text {hitung }}<\mathrm{L}_{\text {tabel }}$ pada taraf signifikansi $5 \%$, yakni $(0,10<0,140)$. Kelompok siswa yang menggunakan media powerpoint juga berdistribusi normal, diketahui dari $\mathrm{L}_{\text {hitung }}<$ $\mathrm{L}_{\text {tabel }}$ pada taraf $5 \%$, yakni $(0,09<0,140)$.

Berdasarkan uji homogenitas diperoleh data hasil belajar sejarah siswa yang dibelajarkan dengan multimedia pembelajaran interaktif dan hasil belajar sejarah siswa yang dibelajarkan dengan media pembelajaran powerpoint adalah homogen. Hal ini diketahui dari besar $\mathrm{F}_{\text {hitung }}$ $<\mathrm{F}_{\text {tabel }}$ pada taraf signifikansi $5 \%$, yakni $(0,41<1,69)$. 
Dengan demikian dapat disimpulkan bahwa sebaran data hasil belajar sejarah siswa yang dibelajarkan dengan multimedia pembelajaran interaktif dan sejarah siswa yang dibelajarkan dengan media pembelajaran powerpoint adalah homogen.

Hasil pengujian data dengan menggunakan uji $\mathrm{t}$ diperoleh nilai $\mathrm{t}_{\text {hitung }}=2,01$. Nilai $t_{\text {hitung }}$ dikonsultasikan dengan nilai $t_{\text {tabel }}$ untuk $\mathrm{N}=40$ diperoleh 1,69. Dengan demikian, nilai $t_{\text {hitung }}>t_{\text {tabel }}(2,01>1,69)$ yang menyimpulkan bahwa Ho ditolak dan $\mathrm{Ha}$ diterima. Maka dapat dinyatakan bahwa hipotesis yang diajukan yakni adalah perbedaan yang signifikan dan berarti antara hasil belajar sejarah siswa yang diajarkan dengan menggunakan multimedia pembelajaran interaktif dengan rata-rata hasil belajar sejarah siswa yang diajarkan dengan menggunakan media pembelajaran powerpoint dapat diterima dan teruji kebenarannya.

Keefektifan multimedia pembelajaran interaktif diperoleh dengan cara sebagai berikut:

$\mathrm{X}=\frac{\text { Jumlah Skor yang diperoleh }}{\text { jumlah gloor ideal }}$

$=\frac{1015}{1600} \times 100 \%=63,44 \%$

Keefektifan pembelajaran dengan media pembelajaran powerpoint adalah:

$\mathrm{X}=\frac{\text { Jumlah Skor yang diperoleh }}{\text { jumlah sloor infeal }}$

$=\frac{916}{1600} \times 100 \%=57,25 \%$

Dengan demikian nilai keefektifan multimedia pembelajaran interaktif lebih tinggi dari nilai keefektifan pembelajaran dengan media pembelajaran powerpoint yaitu sebesar $6,19 \%$.

\section{PEMBAHASAN}

\section{Pembahasan Pengembangan Produk}

Hasil penelitian menunjukkan bahwa pengembangan produk pembelajaran dapat meningkatkan hasil belajar siswa. Hasil penelitian ini mendukung penelitian Permata (2012), Putri (2012), dan Vebibina (2014) yang menyimpulkan bahwa pengembangan media pembelajaran interaktif menggunakan perangkat komputer memberi sumbangan praktisi terutama dalam pelaksanaan proses pembelajaran. Selain itu juga dinyatakan bahwa bagi guru dimana media pembelajaran interaktif ini memberikan kemudahan dalam menyelenggarakan pembelajaran sehingga berdampak pada efektivitas proses pembelajaran dan dapat meningkatkan hasil belajar siswa.

Produk pengembangan multimedia pembelajaran interaktif pembelajaran pada mata pelajaran sejarah merupakan materi pembelajaran yang telah dikembangkan dengan memperhatikan berbagai aspek pembelajaran. Media sebagai desain pesan pembelajaran penelitian perkembangan ini dilakukan untuk menghasilkan suatu produk berupa CD pembelajaran multimedia pembelajaran interaktif untuk kelas X IPS yang bermanfaat untuk meningkatkan hasil belajar siswa.

Proses penelitian ini diawali dari studi pendahuluan, pengumpulan bahan/ materi pelajaran, membuat desain software, membuat dan memproduksi software, review dan uji coba produk yang divalidasi oleh ahli materi, ahli desain intruksional dan ahli media, melakukan analisis data, revisi produk sehingga layak digunakan oleh pengguna yaitu uji coba perorangan, kelompok kecil dan uji lapangan serta penilaian dari pengguna tersebut sehingga menghasilkan produk yang layak dan bermanfaat dalam pelaksanaan proses pembelajaran. Langkah-langkah pengembangan produk pembelajaran interaktif ini telah sejalan dengan pendapat Sugiyono (2012:298) yaitu: (1) identifikasi masalah; pengumpulan informasi; (3) desain produk; (4) validasi desain; (5) perbaikan desain; (6) uji coba produk; (7) revisi produk; (8) uji coba pemakaian; (9) revisi produk tahap akhir; dan (10) produksi massal.

Revisi dilakukan berdasarkan atas penilaian, saran dan komentar dari para ahli materi, ahli desain intruksional dan ahli media pembelajaran serta pengguna media tersebut yang bertujuan untuk mengasilkan produk media yang layak pakai. Variabel-variabel media pembelajaran memiliki nilai rata-rata sangat baik. Adapun variabel media pembelajaran yang dinilai meliputi kelayakan isi, penyajian, kebahasaan, pemrograman dan kegrafikan.

Dengan mempelajari karakteristik pada mata pelajaran sejarah yang membuat berkurangnya minat dan motivasi belajar siswa berkurang sehingga berpengaruh terhadap hasil belajar siswa, disebabkan karena proses pembelajaran yang kurang efektif. Untuk itu perlu pengembangan multimedia pembelajaran interaktif pada mata pelajaran sejarah untuk mengatasi masalah yang telah diuraikan, khususnya dalam pembelajaran sejarah adalah 
sebagian besar siswa tidak mampu menghubungkan antara apa yang mereka pelajari dengan bagaimana pemanfaatannya dalam kehidupan nyata. Salah satu faktor yang menyebabkan timbulnya masalah tersebut yaitu ketersediaan sumber belajar yang masih terbatas secara kualitas maupun kuantitas.

Pembelajaran kontekstual tentu saja membutuhkan sumber belajar yang berbasis kontekstual, Salah satu media pembelajaran yang sangat cocok menggunakan pendekatan kontekstual adalah media interaktif dengan makromedia flash dimana media ini disusun berdasarkan prinsip desain pembelajaran yang disesuaikan dengan materi pokok pengajaran sehingga akan membawa siswa dalam kehidupan nyata. Disamping itu media pembelajaran yang dikembangkan berdasarkan masukkan pada kegiatan analisis kebutuhan pada guru dan siswa untuk memperoleh informasi bahwa media pembelajaran interaktif yang dikembangkan memang dibutuhkan dan dapat memberi kemudahan bagi siswa dan guru sebagai pengguna media. Sehingga pertanyaan di atas dapat diduga bahwa penggunaan media pembelajaran interaktif yang dikembangkan dengan makromedia flash layak digunakan.

Manfaat yang diperoleh dalam menggunakan multimedia pembelajaran interaktif pembelajaran adalah konsep yang disajikan mudah dipelajari, dipahami dan sistematis. Multimedia pembelajaran interaktif pembelajaran memberikan kesempatan pada siswa untuk belajar sesuai dengan karakternya masing-masing, mudah dipahami karena materi dilengkapi dengan gambar dan animasi sejarah peradaban Indonesia dan dunia. Produk media ini dalam bentuk CD yang dapat digunakan dalam pembelajaran secara mandiri maupun klasikal juga dilengkapi dengan latihan menjawab soal untuk mengetahui daya serap siswa setelah selesai proses pembelajaran.

\section{Pembahasan Hasil Penelitian Efektivitas Produk}

Dari hasil pengolahan data penelitian yang dilakukan terdapat perbedaan hasil belajar sejarah pada siswa yang menggunakan multimedia pembelajaran interaktif dangan siswa yang dibelajarkan dengan media pembelajaran powerpoint, yaitu rata-rata hasil belajar sejarah siswa yang dibelajarkan dengan multimedia pembelajaran interaktif lebih tinggi dibandingkan dengan hasil belajar siswa yang menggunakan media pembelajaran powerpoint.
Hasil penelitian ini mendukung penelitian Hendra (2011) dan Lingin (2012) yang menyimpulkan bahwa media pembelajaran interaktif dapat meningkatkan hasil belajar dibandingkan media pembelajaran interaktif offline. Hasil penelitian juga menyimpulkan bahwa pengembangan media pembelajaran interaktif dalam penelitiannya menggunakan model pengembangan produk Bord dan Gall yang dipadu dengan model pengembangan pembelajaran Dick dan Carey ditemukan dari hasil penelitian bahwa terjadi perbedaan terhadap pengguna media interaktif pada tes hasil belajar siswa menunjukkan bahwa hasil belajar siswa yang dibelajarkan dengan menggunakan media pembelajaran interaktif lebih tinggi dari hasil belajar siswa yang dibelajarkan dengan mengguanakan media buku teks yang sudah layak digunakan.

Dari hasil pengujian menggunakan uji-t satu pihak, diperoleh harga $t_{\text {hitung }}=2,01$ dan $t_{\text {tabel }}$ $=1,69$. Jika dibandingkan $t_{\text {hitung }}>t_{\text {tabel }}$ atau 2,01 $>1,69$, dengan demikian dapat dinyatakan bahwa ada perbedaan hasil belajar dengan menggunakan multimedia pembelajaran interaktif dengan siswa yang menggunakan media pembelajaran powerpoint. Hal ini dapat dilihat dari hasil nilai rata-rata sejarah siswa yang diajarkan dengan multimedia pembelajaran interaktif yaitu sebesar 25,38, sedangkan hasil nilai rata-rata sejarah yang diajarkan dengan media pembelajaran powerpoint yaitu sebesar 22,90 dari 34 soal yang diberikan. Data ini membuktikan bahwa penggunaan media pembelajaran interaktif lebih baik untuk meningkatkan pengetahuan siswa dalam pembelajaran sejarah dari pada menggunakan media pembelajaran powerpoint.

Pemakaian media pembelajaran interaktif dengan makromedia flash berbasis CTL dalam proses pembelajaran dapat membangkitkan keinginan dan minat yang baru, diharapkan memotivasi siswa untuk belajar mandiri, kreatif, efektif dan efisien. Dalam mengelola cara belajar guna mendapat hasil pembelajaran yang optimal. Diharapkan dapat mengurangi kejenuhan siswa karena selama ini proses pembelajaran yang dilakukan oleh kebanyakan sekolah adalah metode tatap muka (ceramah) dan berpusat pada guru.

Pembelajaran interaktif yang menggunakan makromedia flash berbasis kontekstul memberikan suasana baru dalam proses pembelajaran bahwa siswa akan belajar dengan baik apabila siswa dapat membawa 
pembelajaran ke dalam konteks apa yang sedang dipelajari ke dalam penerapan kehidupan nyata sehari-hari dan mendapat manfaat bagi dirinya. Hal ini sejalan dengan pendapat Dick dan Carey (2005:14) bahwa pengembangan media pembelajaran interaktif melalui tahap-tahap sebagai berikut: (a) mengidentifikasi tujuan umum pembelajaran, (b) melakukan analisis pembelajaran, (c) identifikasi perilaku dan karakteristik awal, (d) menulis tujuan kerja, (e) mengembangkan tes acuan patokan, (f) mengembangkan strategi pembelajaran, (g) mengembangkan dan memilih materi pembelajaran, (h) mendesain dan melaksanakan evaluasi formatif, (i) merevisi bahan pembelajaran, dan (j) mendesain dan melaksanakan evaluasi sumatif.

Pembelajaran dengan menggunakan powerpoint yang hanya dapat memberikan materi secara pokok, sehingga masih membutuhkan penjelasan dari guru terhadap materi yang akan diajarkan. Powerpoint adalah media pmbelajaran yang sering digunakan namun di dalamnya belum terjadi interaksi antara guru dan siswa. Sehingga dapat dilihat perbedaan antara hasil belajar siswa dengan penggunaan media interaktif dan powerpoint pada pembelajaran sejarah. Pembelajaran menggunakan powerpoint kurang menciptakan pembelajaran yang interaktif dimana siswa bersifat aktif dalam pembelajarannya. Hasil media yang dikembangkan berupa $C D$ pembelajaran interaktif untuk pelajaran sejarah. Siswa akan lebih termotivasi, tertarik dan menambah minat siswa untuk belajar dan diharapkan dapat meningkatkan prestasi dalam belajar. Maka dapat diduga bahwa penggunaan media interaktif lebih efektif dibanding penggunaan powerpoint.

\section{PENUTUP}

Berdasarkan hasil penelitian yang telah diuraikan pada Bab IV, maka dapat disimpulkan:

1. Model pembelajaran interaktif yang dikembangkan penelitian layak digunakan sebagai media pembelajaran sejarah untuk kelas X IPS. Hasil penilaian menunjukkan secara keseluruhan responden dominan menyatakan media pembelajaran interaktif pada aspek pembelajaran, aspek materi, aspek pemrograman, dan aspek tampilan multimedia dengan pilihan jawaban sangat baik lebih besar dari $60 \%$.
2. Model pembelajaran interaktif yang digunakan efektif dalam meningkatkan hasil belajar sejarah pada siswa kelas X IPS. Nilai keefektifan multimedia pembelajaran interaktif lebih tinggi dari nilai keefektifan pembelajaran dengan media pembelajaran powerpoint yaitu sebesar 63,44\% berbanding 57,25\%. Hasil lebih lanjut menunjukkan hasil belajar kelas dengan model pembelajaran interaktif lebih tinggi dibandingkan hasil belajar kelas dengan model pembelajaran powerpoint yakni ratarata 25,38 berbanding 22,90 dari 34 soal yang diberikan

\section{DAFTAR PUSTAKA}

Adriyanto, Bambang. 2010. Modul 10 Pelatihan Pengembangan dan Pemanfaatan Konten Jardiknas Tingkat Nasional Tahun 2010. Pembuatan Animasi Dengan Macromedia Flash 8. Pusat Teknologi Informasi dan Komunikasi Pendidikan. Kementerian Pendidikan Nasional 2010 E-Book: tersedia http://jakapratama.blogspot.com/2014/ 04/download-gratis-ebook-tutorial_ belajar 17.html (online) tersedia

Ali, Muhammad. 2007. Guru Dalam Proses Belajar Mengajar. Bandung: Sinar Baru

Al-Tabany, Trianto Ibnu Badar. 2014. Mendesain Model Pembelajaran: Inovatif, Progresif, dan Kontekstual. Jakarta: Prenadamedia Group

Anggar, Kaswati. 1998. Metodologi Sejarah dan Historiografi. Yogyakarta: Beta Offset

Basieman, Anisah dan Mappa, Syamsu. 2011. Teori Belajar Orang Dewasa. Bandung: Rosda

Dahar, Wilis Ratna. 2010. Teori-Teori Belajar dan Pembelajaran. Bandung: Erlangga

Degeng, Nyoman S. 2013. Ilmu Pembelajaran Klasifikasi Variabel Untuk Pengembangan Teori Penelitian. Bandung: Kalam Hidup

Depdiknas. 2006. Standar isi. Permendiknas No. 22 Tahun 2006. Kurikulum Sejarah SMA. Jakarta: Depdiknas

Dick, Walter. dan Carey, Lou. 2005. The Systematic Design of Instruction. United States of America: Scott Foresman and Company

Ernawati. 2013. pembelajaran sejarah dengan metode skematik (online): tersedia 
http://sejarah-sman1-

tmg.blogspot.com/2013/03/pembelajaran -sejarah-dengan-metode.html (06 juni 2015. 18.00)

Hadi, Ariesto. 2011. Macromedia Flash. Jakarta: E-Book

Hamalik, Oemar. 2003. Manajemen Belajar di Perguruan Tinggi. Bandung: Sinar Baru 2008. Kurikulum dan Pembelajaran. Bandung: Bumi Aksara

Harjanto. 2011. Perencanaan Pengajaran. Jakarta: Rineka Cipta

Hendra, Asbon. 2012. Pengantar Sistem Informasi. Yogyakarta: Andi Yogyakarta

Izham, Dedy. 2003. Cara Cepat Belajar Adobe Flash. $\quad E$-Book: tersedia www.IlmuKomputer.com

Johnson, B. Elaine. 2014. CTL (Contextual Teaching \& Learning) Menjadikan Kegiatan Belajar-Mengajar Mengasyikkan dan Bermakna. Bandung: Kaifa Learning

Kusnadi, Cecep dan Sutjipto Bambang. 2013. Media Pembelajaran Manual dan Digital. Jakarta: Ghalia Indonesia

Muslich, Masnur. 2007. KTSP Berbasis Kompetensi dan Kontekstual. Jakarta: Bumi Aksara

Mustopo, Habib. 2006. Sejarah: SMA Kelas X. Jakarta: Yudhistira

Olson, H. Matthew dan Hergenhahn, B.R. 2008. Teori of Learning. Jakarta: Kencana

Pramono, Andi. 2003. Berkreasi Animasi dengan Macromedia Flash MX. Yogyakarta: Andi

Priyanto, Dwi. 2009. "Pengembangan Multimedia Pembelajaran Berbasis Komputer". Jurnal Pemikiran Alternatif Kependidikan. Vol. 14 No. 1. Jan-Apr 2009

Rusman. 2012. Seri Manajemen Sekolah Bermutu: Model-Model Pembelajaran Mengembangkan Profesionalisme Guru. Jakarta: Grafindo . 2013. Belajar dan Pembelajaran Berbasis Komputer. Mengembangkan Profesionalisme Guru Abad 21. Bandung: Alfabeta

Safitri, Meilani. 2013. "Pengembangan Media Pembelajaran Matematika Pokok
Bahasan Segitiga Menggunakan Macromedia Flash Untuk Siswa Kelas VII SMP". Jurnal Universitas Sriwijaya. Volume 10 No 3 - Agustus 2013

Sanjaya, Wina. 2006. Pembelajaran Dalam Implementasi Kurikulum Berbasis Kompetensi. Bandung: Kencana

Sardiman, A.M. 2008. Interaksi dan Motivasi Belajar Mengajar. Jakarta: Raja Grafindo Persada

Soedijarto. 2007. Menuju Pendidikan Nasional yang Relevan dan Bermutu. Jakarta: Balai Pustaka

Suhana, Cucu. 2014. Konsep Strategi Pembelajaran. Bandung: Aditama

Sumiati dan Asra. 2009. Metode Pembelajaran. Bandung: Wacana Prima

Supriyadi, Y. 2005. "Sumbangan Media dalam Pembelajaran Sejarah". Akademika. Jurnal Ilmiah Kependidikan. Vol. 4. No. 1, April 2005. Halaman 1-14. IKIP PGRI Wates

Surachman, Mardhika. 2015. "Pengembangan Multimedia Interaktif Berbasis Kontekstual Untuk Meningkatkan Keterampilan Berpikir Kritis Siswa Kelas XI Pada Materi Pokok Sistem Koloid". Jurnal Program Pascasarjana Universitas Mataram. Vol 1, No 1 Januari 2015

Susilana, Rudi dan Riyana Cepi. 2009. Media Pembelajaran: Hakikat Pengembangan, Pemanfaatan, dan Penilaian. Bandung: Wacana Prima

Wandah. 2014. Dasar Pemprograman Flash Game. E-Book: tersedia http://jakapratama.blogspot.com/

2014/04/download-gratis-ebook-tutorialbelajar17. html

Waryanto, Nur Hadi. 2014. Tutorial Komputer Multimedia (Macromedia Flash dan ISpring). Laboratorium Komputer Jurusan Pendidikan Matematika Fakultas Matematika dan Ilmu Pengetahuan Alam Universitas Negeri Yogyakarta E-book: tersedia http://jaka-pratama. blogspot. com/2014/04/download-gratis-ebooktutorialbelajar 17.html 